\title{
Which Factors Favour Biodiversity in Iberian Dehesas?
}

\author{
Maria Pilar Rodríguez-Rojo ${ }^{1, *}$, Sonia Roig ${ }^{2}$, Celia López-Carrasco ${ }^{2,3}$, María Manuela Redondo García ${ }^{4}$ and \\ Daniel Sánchez-Mata ${ }^{5}$ (i)
}

1 Institute of Environmental Sciences, Universidad de Castilla-La Mancha, 45071 Toledo, Spain

2 Department of Natural Systems and Resources, Universidad Politécnica de Madrid, 28040 Madrid, Spain; sonia.roig@upm.es (S.R.); celialc@jccm.es (C.L.-C.)

3 Servicio de Política Forestal y Espacios Naturales, Delegación Provincial de Desarrollo Sostenible Toledo, Junta de Comunidades de Castilla-La Mancha, 45600 Talavera de la Reina, Spain

4 Department of Geography, Universidad Complutense de Madrid, 28040 Madrid, Spain; mredondo@ucm.es

5 Department of Pharmacology, Pharmacognosy and Botany, Universidad Complutense de Madrid, 28040 Madrid, Spain; dsmata@ucm.es

* Correspondence: mpilar.rodriguez@uclm.es

check for

updates

Citation: Rodríguez-Rojo, M.P.; Roig, S.; López-Carrasco, C.; Redondo García, M.M.; Sánchez-Mata, D. Which Factors Favour Biodiversity in Iberian Dehesas?. Sustainability 2022, 14, 2345. https://doi.org/10.3390/ su14042345

Academic Editors: Leonardo Montagnani and Sharif Ahmed Mukul

Received: 26 October 2021 Accepted: 15 February 2022 Published: 18 February 2022

Publisher's Note: MDPI stays neutral with regard to jurisdictional claims in published maps and institutional affiliations.

Copyright: (c) 2022 by the authors. Licensee MDPI, Basel, Switzerland. This article is an open access article distributed under the terms and conditions of the Creative Commons Attribution (CC BY) license (https:// creativecommons.org/licenses/by/ $4.0 /)$.

\begin{abstract}
Dehesas or montados are man-made systems whose conservation interest as a Mediterranean landscape or agroforestry system has been highlighted in the scientific literature due to their high levels of biodiversity. The understanding of how management practices influence the biodiversity of the dehesa requires a comprehensive approach that considers the broad spectrum of biological components (i.e., fungi, lichens, vascular plants, macroinvertebrates, and vertebrates) that make the dehesa an ecosystem. We have reviewed around seventy publications compiled through Scopus and other specialized bibliographic sources not included in Scopus that study the impact of land use and land cover on the biodiversity of Iberian dehesas. The most significant results have been organized and summarized into a group of factors related to habitat structure and management practices. The conclusion to be drawn from the scientific studies is that not all biological components respond in the same way to land-cover and human practices, and the maintenance of a high overall diversity in dehesas depends on a complex understorey vegetation and habitat heterogeneity.
\end{abstract}

Keywords: biodiversity conservation; dehesa; diversity; montado; Portugal; Spain; species richness; wood pastures

\section{Introduction}

Dehesas or montados (hereafter dehesas) are examples of whole-farm High Natural Value Farmland (HNVF) and agroforestry systems with an important cultural value characterized by low-intensity management of all land [1,2]. The main land use is extensive permanent grazing at low stocking densities (cattle, sheep, pigs, and goats), although other types of farming management include cork extraction, fodder crops, timber, honey, mushrooms, and medicinal plants [3]. They cover an estimated area of 737,000 ha in Portugal and 2,300,000 ha in Spain [2]. The landscape structure is characterized by an open grassland with scattered oak trees $\left(<80\right.$ trees $\left.\mathrm{ha}^{-1}\right)$, mainly cork and holm oaks, often with a mosaic of shrubs and crops and occasionally with other landscape features such as streams, ponds, and forest patches. This low-intensity farming system produces an intimate mixture of habitats that support a rich diversity of plants and animals due to a variety of grazed, shrubby, and cultivated types of habitats and other features, with differences in the structure and composition of the land cover (Figure 1).

Dehesas are considered a habitat type of European Community Interest (Habitat 6310), according to Directive 43/92/ EEC [4], and are known for hosting important levels of biodiversity and providing ecosystem services and commercial goods [5-10]. The consideration of HNVF in dehesas has been justified based on the fact that they generate habitats containing species of concern for European conservation or are associated with 
high species and habitat diversity, or both [11,12]. The preservation of biodiversity in dehesas depends not only on their extension but also on the condition of the habitats present and on their high structural diversity [13]. Over the last few decades, traditional dehesas have been facing a variety of threats that endanger the sustainability of their ecosystems and their high natural value: oak decline [14], lack of oak regeneration [15,16], and abandonment or intensification $[17,18]$. One problem highlighted in the maintenance and persistence of the traditional use of the dehesa is the lack of skilled labour owing to the aging of the rural population $[19,20]$.

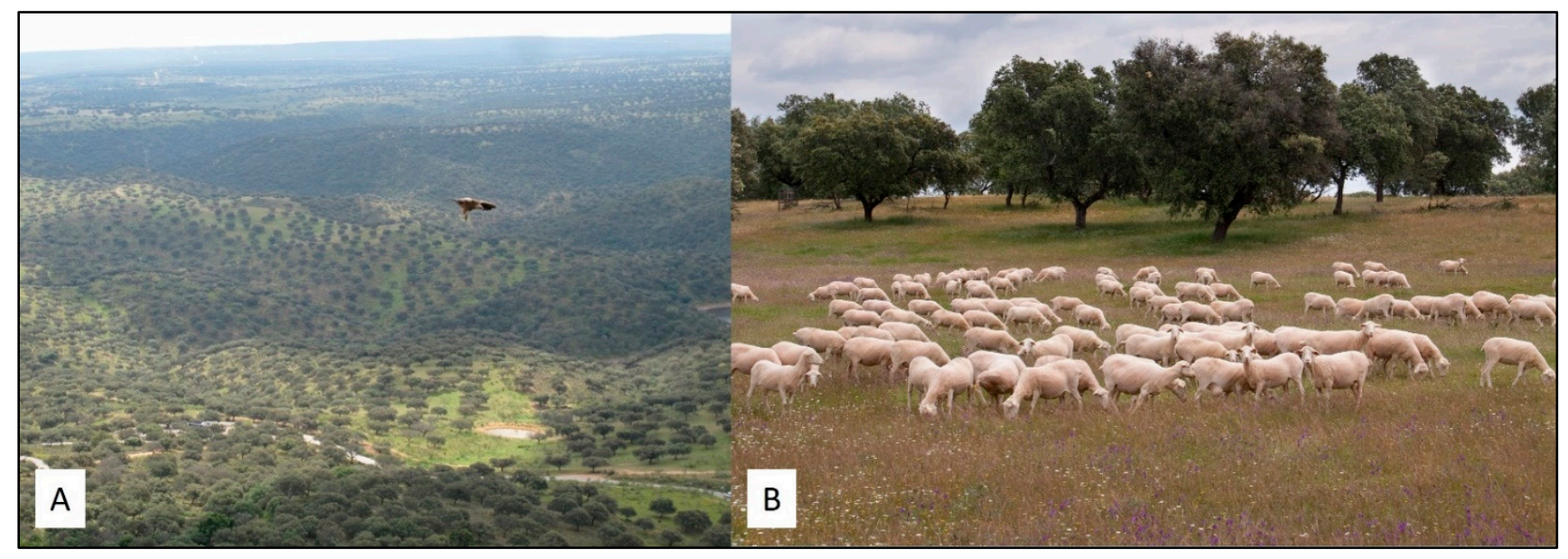

Figure 1. (A) Landscape view of a dehesa characterized by a mixture of habitats, National Park of Monfragüe (Spain) (J.L. Nieves); (B) view of a dehesa with extensive permanent grazing of sheep livestock, Oropesa (Toledo, Spain) ((A) San Miguel). Photos reproduced with permission from the authors.

Dehesas sustain a high species richness in several contrasting taxonomic groups: soil fungi, bryophytes, lichens, and vascular plants; macroinvertebrates such as ants, bees, butterflies, spiders, coleoptera, syrphids, and earthworms; and vertebrates such as reptiles, birds, and mammals [2]. The emblematic species most often cited to raise the importance of dehesa biodiversity are large vertebrate species of high concern for conservation, such as the Iberian lynx (Lynx pardinus), the Spanish imperial eagle (Aquila adalberti), the black stork (Ciconia nigra), or the cinereus vulture (Aegypius monachus) [21]. The assessment of the biological conservation of dehesas has focused mainly on these threatened or keystone species, rather than on diversity values for several contrasting taxonomic groups associated to these ecosystems [22]. The first works on the quantification of dehesa biodiversity studied the floristic component based on diversity indices (e.g., species richness, Sorensen index, Shannon index) [23-26], while studies of other biological components (e.g., reptiles, macroinvertebrates, and fungi) did not appear until the 2000s. Since Díaz's 2009 review [27] of the biodiversity in the dehesa, a significant number of publications have covered the effect of land management, the spatial structure of land cover, and habitat heterogeneity on various biological groups at the farm scale. Most studies deal with one taxonomic group, except for a few that focus on several groups (i.e., vascular plants, birds, and various macroinvertebrates [28-30]). A bibliographic review of the effect of habitat structure and human practices on the biological components is therefore crucial at this time to understand the best practices that promote a high natural conservation value from a broad taxonomic perspective and to cover gaps in the scientific literature concerning certain practices or taxonomic groups.

Our main objective is to provide a synthesis of the effects of management practices and the spatial structure and composition of land cover on dehesa biodiversity. We carried out a literature review of the publications that deal with biodiversity studies on any biological component of the dehesas in the Iberian Peninsula. Specifically, our aims are 
(i) to quantify the number of studies per biological group and analyse temporal trends in thematic issues; (ii) to identify associations between land cover and biodiversity and land management and biodiversity at the habitat and landscape scale; and (iii) to synthetize some recommendations contained in the literature to promote high biodiversity levels in dehesas.

\section{Methods}

We undertook a systematic literature review by means of a search for Scopus publications containing a combination of the following terms in the title, keywords, or abstract: (richness or diversity or biodiversity) and (dehesa/s or montado/s or "wood pastures"). The initial Scopus search yielded 208 documents (search date 7 January 2021). We used revtools to visualize trends in the titles, abstracts, and keywords and selected 48 publications that deal with studies of the effect of the structure and composition of land cover and other habitat features and management on the biodiversity of Iberian oak-tree dehesas. We also examined other specialized publications such as the journal Pastos and the conference proceedings of the European Grassland Federation and the Spanish Society for the Study of Pastures, which are not included in international databases such as Scopus, Web of Science, or Google Scholar. We avoided repetitions of any research that had been recently published in an international journal in Scopus. We also examined the bibliographies of these papers and read any additional papers or books that appeared to be relevant.

Finally, 67 documents were assessed for eligibility in our literature review, 62 from journals and 5 from conference papers, all of which include quantitative measurements using taxonomic diversity indexes (e.g., species richness, Shannon index, Pielou index, Whittaker index, etc.) of various biological components: vascular plants, lichens, macrofungi, macroinvertebrates, reptiles, birds, and mammals. From each publication, we extracted information on the biological component, management practices, grazing intensity, land use, and habitat features related to the study, quantitative indices for the measurement of biodiversity, and the dominant tree species in the dehesas (or montados). We summarized the temporal trend of the studies for each biological component by categorizing the variability in the biological components in main taxonomic groups. We differentiated studies on mammals according to their body size: small mammals (e.g., rodents, shrews, and moles) and mesomammals (e.g., mesocarnivores and lagomorphs). The selection of bird studies was based on small and medium-size birds. Large bird studies were excluded as they focused on the effect of habitat management on their population size, such as the common crane (Grus grus) [31,32], cinereous vulture (Aegypius monachus) [33], and griffon vulture (Gyps fulvus) [34]. Macroinvertebrates comprise a large number of taxonomic groups studied in the literature (ants, coleoptera, diptera, bees, butterflies, spiders, nematodes, etc.). Other main taxonomic groups found in the literature were reptiles, vascular plants, epiphytic lichens, and soil fungi. No studies were found on mosses in dehesas.

\section{Results and Discussion}

Vascular plant studies were predominant in the literature, followed by macroinvertebrates. Coleoptera were the most studied group of macroinvertebrate taxonomy, followed by ants. In the 1980s, the studies on dehesa biodiversity focused only on vascular plants, and no studies on any other biological components appeared until the 1990s. The temporal tendency of biodiversity studies on dehesas revealed a significant increase in the number of publications in the last decade and was the same for macroinvertebrates and vascular plants (Figure 2).

To summarize the main questions addressed in the publications on the effect of land cover and land-use factors, we have categorized them according to the list in Table 1 . The main factors are habitat heterogeneity (e.g., heterogeneity of tree density, shrub patchiness, presence of riparian galleries, orchards, ponds, etc.), microhabitat variability (e.g., stone piles, pruning piles, canopied shrubs), tree density and shrub vegetation cover, the oak-canopy effect, and soil topography. The main land-use factors at the farm level are 
shrub control practices (clearing), grazing management (intensity and abandonment) and grazing animals, agricultural use, and phosphorus fertilization. Habitat heterogeneity was mostly studied for mammals, birds, reptiles, and macroinvertebrates; the tree canopy effect, for vascular plants, fungi and ants; shrub control practices, for macroinvertebrates and fungi; and grazing intensity and abandonment, for macroinvertebrates and vascular plants. Topography and phosphorus fertilization were studied for vascular plants. Other management practices that were scarcely covered in the literature are canopy pruning, cork extraction, and legume sowing.

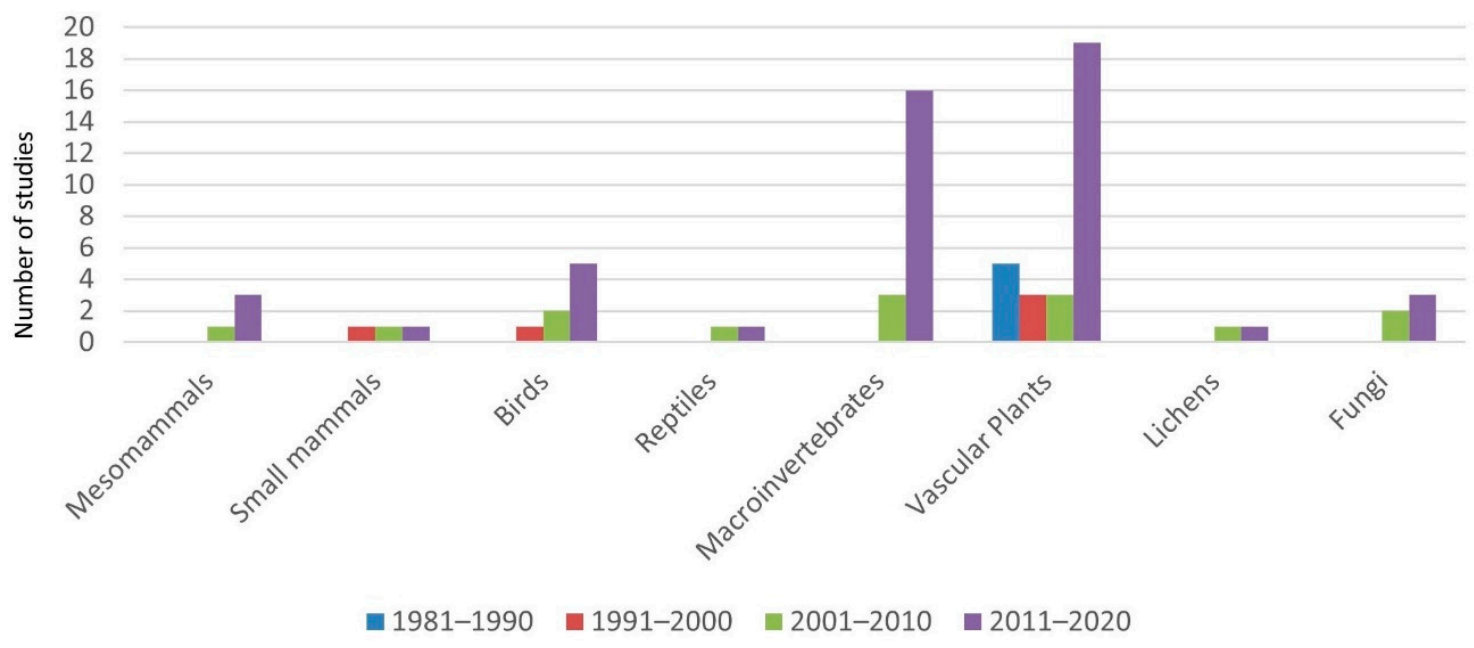

Figure 2. Temporal tendency of number of studies for each main taxonomic group.

Table 1. List of studies on the effect of land cover and land-use factors on dehesa biodiversity.

Marañón (1985, 1986) [24,35]; Rico and Puerto (1988) [25];

Díez et al., (1992) [36]; Fernández-Moya et al., (2011) [37]; López-Carrasco et al., (2015) [38];

López-Sánchez et al., (2016a, 2016b) [39,40];

Tree factor (tree presence and density)

Rolo et al., (2015) [41]; Rolo et al., (2016) [42]-vascular plantsReyes-López et al., (2003) [43]; Gaytán et al., (2021) [44]-antsMartins da Silva et al., (2009) [45];

Ramirez-Hernández et al., (2014) [46]; García-Tejero and Taboada (2016) [47]; Cárdenas et al., (2020) [48]-coleopteraRicarte et al., (2018) [49];

Ramirez-Hernández et al., (2014) [46]-syrphidsSantos-Silva et al., (2011) [50]-macrofungi-

Canteiro et al., (2011) [51]-vascular plants-

Martín and Lopez (2002) [52]; Godinho et al., (2011) [53]-reptiles-

García-Tejero and Taboada (2016) [47];

Cárdenas et al., (2020) [48] -coleoptera-

Shrub (shrub cover, shrub clearing practices)

Ramirez-Hernández et al., (2014) [46]-coleoptera, syrphids-

Oksuz et al., (2020) [54] -vascular plants, lichens, coleoptera-

Slancarova et al., (2015) [55]-butterflies-

Simonson et al., (2018) [30]-vascular plants, butterflies, birdsAzul et al., (2010, 2011) [56,57]; Barrico et al., (2010) [58];

Santos-Silva and Louro (2016) [59]-macrofungi-

Mendes et al., (2011) [60]-soil macroinvertebrates- 
Table 1. Cont.

Land Factors

Topography

Phosphorus fertilization

\section{Publications}

Pineda et al., (1981) [23]; Puerto et al., (1990) [26];

Peco et al., (1998) [61]; Peco et al., (2006) [62];

Carmona et al., (2012) [63]; Garcia del Barrio et al., (2014) [64]; López-Carrasco et al., (2015) [38]-vascular plants-

Rico et al., (1985) [65];

López-Carrasco et al., (2012, 2013, 2014) [66-68]-vascular plants-

Peco et al., (2006) [62]; Tárrega et al., (2009) [69]; Castro et al., (2010) [70]; Rueda et al., (2013) [71]; Carmona et al., (2012) [63];

López-Sanchez et al., (2016a, 2016b) [39,40];

Köbel et al., (2021) [72]-vascular plants-

Aragón et al., (2010) [73]-epiphytic lichensAzcárate and Peco (2012) [74]-ants-

Grazing management and land use

García-Tejero et al., (2013) [75]-coleopteraMartins da Silva et al., (2009) [45]; Barriga et al., (2010) [76]-spidersArosa et al., (2016) [77]-soil nematodes-

Bugalho et al., (2011) [28]-vascular plants, soil macroinvertebrates-

Pulido and Díaz (1992) [78]; Godinho and Rabaça (2011) [79];

Catarino et al. (2016) [80]; Oksuz et al., (2021) [81]-birdsDíaz et al., (1993) [82]-small mammals-

Marañón (1985) [24]-vascular plants

Moreno et al., (2016) [29]-vascular plants, bees, spiders, nematodes-

Simonson et al., (2018) [30]-vascular plants, butterflies, birdsJiménez-Carmona et al., (2020) [83]-ants-

Godinho et al., (2011) [53]-reptiles-

Martins da Silva et al., (2011) [84];

Habitat heterogeneity and microhabitat variability

García-Tejero and Taboada (2016) [47]-coleoptera-

Pulido and Díaz (1992) [78]; Tellería (2001) [85];

Díaz et al., (2003) [86]; Godinho and Rabaça (2011) [79];

Catarino et al., (2016) [80]-birds-

Rosalino et al., (2009) [87]; Gonçalves et al., (2012) [88];

Curveira-Santos et al., (2017) [89] -small mammals, mesomammals-

Costa et al., (2019) [90] -bats-

Legume sowing: Hernández-Esteban (2019) [91]-vascular plants-

Cork removal: Godinho and Rabaça (2011) [79];

Leal et al., (2011) [92]-birds-

Others

Canopy pruning: Leal et al., (2013) [93]-birds-

Large-nested bird colonies:

López-Sánchez et al., (2019) [94]-vascular plants-

We synthesized the most significant conclusions of these studies in order to understand the effect of dehesa land use and management on diversity under a broad taxonomic perspective but also with an in-depth focus on vascular plants.

\subsection{Tree Factor}

One of the most studied aspects in dehesas is the effect of trees on the floristic composition of the understorey. Several authors have reported the effect of trees on the diversity indices (richness and Shannon index) of the herbaceous layer by comparing small plots beneath the canopy, at the canopy edge, and beyond the canopy [24,35-41]. They coincided in finding higher species richness at the edge of the canopy radius, or ecotone, than under the oak canopy near the trunk, independent of plot size $\left(0.25 \mathrm{~m}^{2}, 1 \mathrm{~m}^{2}, 4 \mathrm{~m}^{2}\right)$, although 
the results are contradictory when comparing the canopy edge and adjacent open sites. López-Sánchez et al. [40] concluded that species richness is higher beyond the canopy influence than in the ecotone, and these differences were more marked in the case of sheep management than on sites grazed by cattle. Fernández-Moya et al. [37] found higher average richness and Shannon index values only in open sites at a defined distance from the crown $(1.5 \times$ crown radius) with SW orientation, while Marañón [35] reported higher average species richness in the canopy edge than in open grasslands, and Díez et al. [36] found that the maximum richness values corresponded to the canopy edge and to the south of the oak tree. Higher species richness in the canopy edge is in agreement with the ecotone theory [95], in which grasslands in ecotone sites may benefit from the transition of two microhabitats, leading to a high level of light radiation and a high soil nutrient content. Higher species richness in open grasslands agrees with the humped-back model of richness and productivity [96]: if open habitats are low-medium productive systems compared to the higher productive conditions in the canopy edge, then these are less diverse as a result of competitive exclusion. However, all authors found a significant number of exclusive species beneath the canopy and in open sites, which supports the idea that isolated oak trees contribute to plant richness in the dehesa system at the landscape level. Indeed, Rolo et al. [42] demonstrated that dehesa farms with more woody features contribute to higher ß-diversity than farms with fewer woody features and suggested a maximum conservation potential in terms of number of species at intermediate values of woody cover (ca. $30 \%)$.

The presence of trees on open grasslands is also a positive factor for diversity in ants $[43,44]$, coleoptera and diptera [45-49]. Ant species richness and Shannon diversity tend to increase in areas under Q. rotundifolia canopies as a consequence of the shade effect, as tree size plays an important role in the density of ground ant nests. Saproxylic beetle diversity positively depends on tree diameter, the formation of scars and cavities in old trees and pollarded or lightly pruned trees favours the colonization of a wide variety of saproxylic insect species; and fungivorous beetles feed on fungus in decaying wood. The effect of tree density is important for macroinvertebrates up to a certain limit, beyond which the trend becomes negative in some studies. Santos-Silva et al. [50] proposed some forest management practices for maintaining a canopy cover value of approximately $30-50 \%$ to enhance macrofungal richness and sporocarp production.

\subsection{Shrub Factor}

The effect of understorey shrubby vegetation on biodiversity differs depending on the taxonomic group studied. The abundance and richness of lizards is greater when the understorey shrubby vegetation increases, as it protects them from predators, and is also related to low stocking rates [52,53]. Oksuz et al. [54] demonstrated that the presence of small shrub patches $\left(252-3000 \mathrm{~m}^{2}\right)$ substantially increased species richness for plants, lichens, and coleopterans as they contain very different species assemblages from in the wood-pasture matrix. Ramirez-Hernández et al. [46] and Cárdenas et al. [48] have detected a greater richness of saproxylic beetles in areas with scarce shrub cover and note that open areas contain greater amounts of accumulated dead wood, which favours saproxylic populations. However, the diversity of saproxylic syrphid species mainly depends on the shrub cover and diversity, which provide sources of pollen and nectar for feeding. Beetles are trophically diverse, and shrubby patches serve as feeding resources, breeding sites, shelter, and microclimate refuges [54]. For example, García-Tejero and Taboada [47] found that microhabitats of scattered shrubs in wood pastures contained a high richness in carabid (seed-eaters and predators) species. For other taxonomic groups, late successional stages resulting from long-term abandonment have a negative effect on butterfly species richness and abundance [55], although shrub patches in dehesas are unlikely to harm butterfly fauna provided open herb-rich areas are maintained [30].

The effect of the shrub management system is the most widely studied aspect in macrofungi and soil epigeic macrofauna [56-60]. A comparison of different management 
practices to control shrub density showed that the diversity of mycorrhizal fungi and soil macrofauna was highest in stands with shrub control by means of cutting practices with no soil tillage. Mulching was another technique that caused a slight decrease in mycorrhizal species and a slight increase in saprotrophic species compared to untreated stands [59]. Mendes et al. [60] found that some macroinvertebrate groups (i.e., Formicidae, Scydmaenidae, Araneae) were associated with shrub-clearing zones intervened at intervals of more than three years and showed high diversity, which supports a sustainable management strategy of shrub clearing every 5-6 years interspersed in space. To promote diversity in plants, a shorter three-year cycle is proposed by Canteiro et al. [51] after finding the highest plant species richness and diversity recorded two years after shrub cutting in a dehesa with a shrub understorey dominated by Cistus salviifolius, which subsequently decreased as shrubs became increasingly dominant.

\subsection{Topography}

Dehesas usually occupy gently sloping lands and sometimes plains [97]. Processes of denudation, transport, and accumulation of nutrients occur when the landscape is characterized by undulating hills with a differentiated slope-valley system, together with regulation of the soil water storage capacity associated to the topographic position [62]. These processes result in a fertility gradient and a variation in the intensity of land use management in dehesas. More fertile and productive soils are located on the lower slopes and valley bottoms and must withstand intensive grazing pressure, while the less fertile soils on higher slopes are subject to lower pressure [26].

Some authors have studied the effect of a trophic gradient derived from a topographic sequence on plant species richness and composition variation. Puerto et al. [26] observed maximal species richness, diversity, and heterogeneity on moderately fertile sites on sloping terrain, and the lowest diversity on eroded sites on hilltops. Diversity values in eutrophic communities on valley bottoms were much lower, as expected due to the negative effect of grazing pressure, and maximal diversity values are associated with intermediate levels of grazing pressure. López-Carrasco et al. [38] found a different pattern in same-sized plots $(0.50 \times 0.50 \mathrm{~m})$ : sites in valley bottoms had higher species richness values than higher zones on hilltops, while del Barrio et al. [64] obtained similar results on large plots $\left(1000 \mathrm{~m}^{2}\right)$. Here, grazing intensity plays an important role in the variation of species richness, which reaches a maximum with intermediate levels of disturbance; this factor may predominate over topography and the fertility gradient. Carmona et al. [63] studied a different perspective and confirmed that the effect of grazing on various diversity components is contingent on water availability, which is conditioned by habitat type (lower/upper slope) and yearly rainfall (wet/dry years). They found that water stress (dry year in dry habitats) caused grazing to have a negative effect on taxonomic diversity, while this effect was positive when water availability was high (wet year in wet habitats), this diversity increased with higher grazing pressure.

\subsection{Fertilization}

Dehesas usually occupy poor, acidic, shallow, and nutrient-poor soils [98,99], which limit the productivity of their pastures. In general, legume production, and hence the pasture protein content, is low and variable. The application of phosphorus fertilizers (e.g., lime superphosphates) to increase legume biomass is a common strategy to improve the production and quality of herbaceous pastures, always combined with cattle or sheep grazing [98]. Legumes favour the entry of nitrogen into the system by means of symbiotic fixation, which in turn requires the contribution of phosphorus. This improvement technique has been applied in Iberian dehesas since the second half of the 20th century [100] based on the results obtained in other Mediterranean territories [101]. Regular phosphorus fertilization is also required when pastures are improved by sowing legumes, a common technique worldwide that can impact pasture diversity and species composition [91]. 
Phosphorus fertilization has been the subject of numerous studies, but only from an agronomic approach. The scarce literature on the effects of phosphorus fertilization on plant diversity denotes a lack of interest in this topic, despite the fact that the dehesa is a habitat type of community interest. Specific studies on floristic composition and biodiversity of vascular plants were found in the journal Pastos and in conference proceedings. Rico Rodríguez et al. [65] compared the effect of two types of fertilizers, superphosphate vs. ground rock, on Shannon diversity values, which was negative at increasing application rates. The effect of phosphorus fertilization in dehesas is conditioned by the rainfall regime: in dry years, the application of $\mathrm{P}$ is not effective, as there is no incorporation of $\mathrm{P}$ into the soil and no increase in assimilable P [102]. López-Carrasco et al. [66,67] compared the effects of applying two commercial fertilizers, phosphate rock and the NPK complex (8-24-8), with moderate equal doses of $\mathrm{P}_{2} \mathrm{O}_{5}$, and found the highest values of species richness and Shannon diversity compared to the control in normal or wet years. This positive effect of fertilizers was maintained the year following the fertilizer input [68].

\subsection{Grazing Management and Land Use}

Grazing abandonment is also associated to a decrease in land-use intensity and the abandonment of cropping under the traditional rotation scheme of crops/fallow/pasture. This has a significant effect on vegetation composition in dehesas. Studies have shown a rapid turnover in species composition from grazed to abandoned sites as the vegetation changes from herbaceous to shrub dominated communities [62,69,70]. Castro et al. [70] found that species richness was also strongly affected by long-term abandonment, and the highest species diversity was associated to grazing [62]; while Tárrega et al. [69] found no significant differences but concluded that long-term grazing abandonment causes the loss of more than $60 \%$ of grassland species in dehesas and a substantial decrease in the rate of annual herbaceous species.

Temporary exclusion of grazing, used as a passive restoration strategy, benefits the regeneration of oak trees and the structure and diversity of the understory shrub community $[72,103]$. An optimal grazing management would be a combination of different grazing intensities to create a landscape mosaic with an enhanced effect on floristic diversity on a regional scale [104,105].

Few studies have explored the effect of the type of grazing animal. When comparing three management regimes (cattle, sheep, and wild ungulates), López-Sánchez et al. [39] observed that cattle livestock generated a more diverse plant community at the plot scale, although no beta diversity differences were found between the three management regimes beneath and outside the canopy. Although sheep grazing is often said to produce a higher floristic and community heterogeneity than cattle grazing at the landscape level [106], Almeida et al. [17] demonstrated that higher intensities of sheep grazing ( $>1.20 \mathrm{LU} / \mathrm{ha})$ may have negative effects on dehesa heterogeneity, as sheep prefer shrubs whereas cattle choose grasses and forbs during the main grazing season.

In the case of non-vascular plants, epiphytic lichen species respond to the eutrophication of bark ammonia deposition from agricultural activities and livestock management, and bark erosion, so species richness is higher in abandoned dehesas. Lichen composition also differed significantly among abandoned, cultivated, or grazed dehesas [73].

For macroinvertebrates, the response to the abandonment of traditionally farmed dehesas differs according to the faunal group. Azcárate and Peco [74] found notable differences in the ant community between grazed and abandoned dehesas, with the latter showing a greater richness of ant species, which is explained by the greater structural complexity and spatial heterogeneity of the vegetation in the abandoned system. In contrast, the rate of ground-dwelling beetles was higher in grazed than in abandoned dehesas or under a mechanical shrub cutting management, as they benefit from the livestock faeces that provide a suitable habitat for coprophagous insects and seeds for seed-eater species [75]. Martins da Silva et al. [45] also found a higher species richness of ground beetles in open as opposed to closed dehesas without grazing and compared rove and ground 
beetle diversity in agricultural crops (permanently irrigated alfalfa monoculture); for both groups, the highest species richness and abundance were recorded in the agricultural landscape. In this case, the crop is a permanently irrigated alfalfa monoculture that provides a suitable habitat in terms of moisture conditions and resource availability for specialists in agricultural areas. The effect of agricultural crops in dehesa farms was also studied for other groups, confirming that cultivated dehesas also host high rates of spider species richness, as they share many species from adjacent grazed dehesas [76], and that high rates of earthworm diversity at the landscape scale were found not only in woody habitats but also in agricultural crops [29].

Pulido and Díaz [78] previously reported that grazing dehesas had a high richness in passerine bird species in plots of 2.5 ha compared to cultivated and scrub dehesas. The effect of dehesa farm management on birds was subsequently assessed at the landscape level through variables that reflect habitat heterogeneity, decoupling the species richness into bird guilds (e.g., forest specialists, farmland specialists, and generalists) [79,80]. Oksuz et al. [81] demonstrated that changes in vegetation structure and habitat heterogeneity linked to land abandonment influence the trait-level diversity of birds during the breeding season but not taxonomic diversity.

\subsection{Habitat Heterogeneity}

One of the first studies on the biodiversity of Iberian dehesas was Marañon's work on vascular plants, which reported 135 species in 0.1 ha in a holm oak dehesa, conditioned by its habitat heterogeneity. Subsequently, in the present century, studies on several taxonomic groups have demonstrated that the heterogeneity of spatial habitats, resulting in a wide variety of habitats and microhabitats inhabiting wood pastures, improves the overall diversity at the landscape level. Moreno et al. [29] highlighted the importance of microhabitats and marginal habitats on plants, bees, spiders, and earthworms, and Jiménez-Carmona et al. [83] did likewise for ants. Farms with different microhabitat types (i.e., linear features, temporary water courses, scrub patches, and traditional stone walls) showed an increased number of species, since unique species were found in every habitat type and contributed to the overall diversity. The maintenance of habitat patches with higher moisture conditions, such as irrigated orchards and riparian gallery habitats, favours ground and rove beetles which are better adapted to moderately high moisture conditions in the soil litter [84]. The anthropic management of dehesas may also create litter-trapping microhabitats such as scattered shrubs, canopied shrubs around the trunk of mature trees, and piles of pruning debris, which are essential for the abundance and diversity of communities of ground-dwelling arthropods [47] and contribute to the biological diversity of dehesas.

Multi-scale habitat heterogeneity in the dehesa landscape benefits the biodiversity of plants and macroinvertebrates, as we have seen before. The diversity of breeding bird species follows a similar trend: the presence of different guilds of birds, farmland and forest species, is associated with a patchwork of habitats dominated by wood pastures, but with a heterogeneous tree density mixed with open areas and undisturbed patches of forest and scrublands [30,78-80,85,86].

Spatial heterogeneity also plays an important role in promoting non-flying mammal diversity. Several studies have demonstrated that dehesa areas with diverse shrub structures, densities, and irregular shapes have a higher relationship with mammal species richness [87-89]; that understory heterogeneity with dense and sparse shrubs promotes the abundance of generalist medium-size Iberian carnivores as it reduces interspecies competition and enhances the high-diversity sympatry of species within the same trophic level [89]; that small patches of shrubs at the base of tree trunks are also beneficial to small mammals, which are crucial in the absence of a dense understory [88]; and that riparian patches in the landscape that act as continuous vegetation corridors that provide shelter, food, water, and dispersion routes and prevent habitat fragmentation are key factors for the conservation of a high number of species of small and medium-size mammals [87,107]. 


\section{Conclusions}

Dehesa farms are Mediterranean agro-forest systems that can sustain high levels of biological diversity under an adequate management regime. We therefore present a literature review of the most influential and widely studied factors for dehesa biodiversity. Scientific research has demonstrated that not all biological components respond in the same way and that a suitable conservation strategy for the dehesa ecosystem can be undertaken following a broad taxonomic perspective. We expected to find more scientific publications on the response of biodiversity to the grazing management regimes that are specific to dehesas, such as livestock type, animal density, or grazing pressure. Similar studies can be found in the assessment of Mediterranean grasslands [108-111]. One unresolved issue is the impact of cattle versus sheep and the combination of both species on vegetation composition and structure and, directly or indirectly, on other biological components of the dehesa ecosystem. Research on this topic will provide a scientific basis for stakeholder decision-making in agricultural and conservation policies.

This literature review examines which factors favour the taxonomic diversity of Iberian dehesas; however, a promising field of study is the assessment of functional diversity, which has potential consequences for the provision of ecosystem services such as soil fertility, soil carbon storage, and soil microbial activity $[10,112,113]$. Studies on the response of functional groups to land use and management will provide a comprehensive understanding of their impact on the functional variability of biological communities [81,114-116].

This literature review offers an overarching synthesis of the recommendations to promote high biodiversity levels in dehesas (Figure 3). Actions at the habitat scale in dehesa farms with small extensions may include the presence of an intermediate tree cover, shrub patches and small-scale features, and natural microhabitats. An intermediate tree cover (30-40\%) can be beneficial for some biological groups (ants, coleoptera, diptera, and soil macrofungi) because of the positive effect of the interception of solar radiation, litter accumulation, and the creation of microclimates under the canopy with less temperature and water variability. The presence of old trees with scars and cavities is also crucial for hosting saproxylic insects. Preserving small shrub patches is inexpensive and easy to implement in conservation strategies for certain biological components such as macroinvertebrates and small vertebrates and also facilitates the regeneration of oak trees $[7,103]$. Although the traditional scheme of crop rotation/fallow/pasture interspersed in space may control shrub encroachment, new insights show that shrub control practices based on shrub cutting without soil tillage has less severe consequences for soil biodiversity and that the cycle time has an effect on maximum biodiversity peaks. The permanence of shrub patches depends on the particular goal we are seeking to achieve: promoting biodiversity, habitat for game, tree nursery, or soil rehabilitation [51]. Small-scale features and natural microhabitats such as traditional stone walls, canopy shrubs, piles of pruning debris, or temporary watercourses have been shown to contribute substantially to the biodiversity of macroinvertebrates, reptiles, and small mammals.

This literature review revealed that agronomic practices for the maintenance of the dehesa system have a variable effect depending on their type and level of intensity. Phosphorus fertilization is a technique that favours the abundance and richness of legumes and hence the productivity of grasslands. Moderate doses of $P$ fertilization (i.e., 27-36 UF $\mathrm{P}_{2} \mathrm{O}_{5}$ during the first year and 18-25 years thereafter [98]) are aimed at favouring legumes and also have a positive effect on the total richness of vascular plants. As mentioned above, soil tillage is a common practice to avoid shrub encroachment, but if performed frequently, it has a negative effect on soil biodiversity due to the destruction of the fungal mycelium by machinery, soil mobilization, and a decrease in the number of seeds in the soil bank. Alternative techniques for biodiversity conservation that are more beneficial are mechanical clearing with no subsequent soil disturbance interspersed in space and applied every 5-6 years or controlled low-intensity grazing, which also favours the implantation of seminatural grasslands that are richer in species and legume cover [108]. Optimal stocking rates for dehesas are $0.2-0.5 \mathrm{LU} / \mathrm{ha}$ [98] with an even distribution to reduce 
damage to the tree layer, avoid soil compaction, and increase the efficiency of grazing on the maintenance of the taxonomic diversity of the biological groups directly or indirectly associated to livestock farming (i.e., coleoptera and birds). Higher stocking rates and a lack of livestock management leads to poor sites with annual nitrophilous grasslands, a more homogeneous landscape and loss of biodiversity at several spatial scales [22,117]. Other agroforestry practices found in the literature are cork extraction and canopy pruning, whose effect was studied on bird species richness. For bird conservation, the authors recommended maintaining a mosaic of fields with different cork ages, or alternatively, the coexistence of cork of different ages in the same fields, and avoiding high-intensity maintenance pruning $[79,92,93]$.

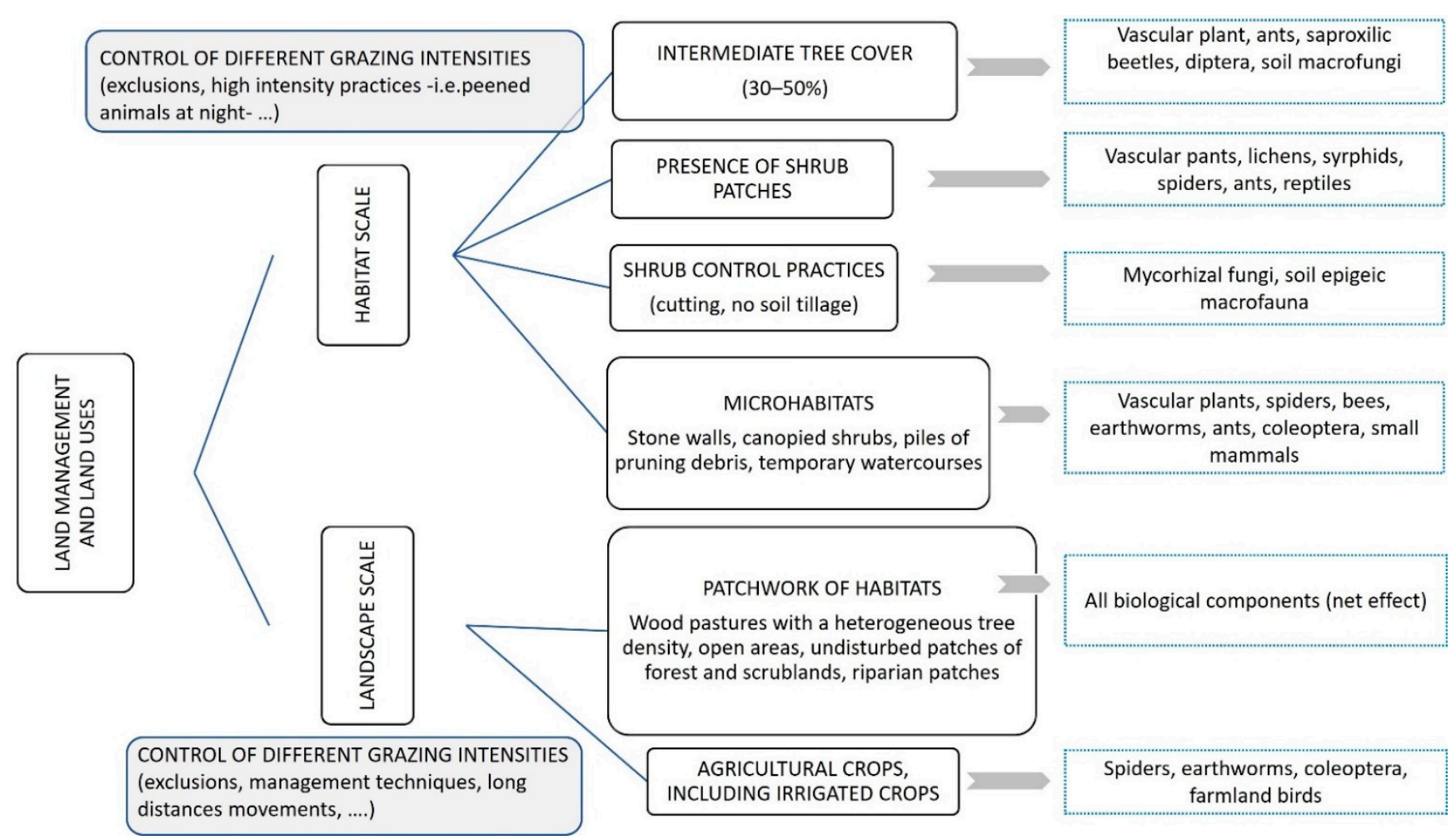

Figure 3. Diagram showing the types of land management and land uses that are beneficial for the biodiversity of dehesas.

Actions at the landscape scale should be undertaken considering the coexistence within dehesa farms of a wide mosaic of habitats, which may be possible in dehesas with a large extension (hundreds of hectares). A patchwork with wood pastures and heterogeneous tree densities, open areas, and undisturbed patches of forest and scrubland has a net beneficial effect on biodiversity and is essential to the conservation strategy for mammal and bird species richness. The preservation of a dense riparian vegetation must also be considered when promoting mammal richness in a Mediterranean landscape such as a dehesa. Although cultivated dehesas have lower levels of diversity than grazed dehesas, the management of small agricultural crops within dehesa farms may contribute to enhancing overall biodiversity thanks to their positive effect on spiders, earthworms, coleoptera, and farmland bird species. Livestock management is the main factor in the creation of open areas and the maintenance of the different types of pastures associated with a wide range of grazing intensities, modulating the interaction between open areas, dense forests, and scrubland areas.

For the preservation of a high biodiversity in Iberian dehesas, it is essential for society to recognise the ecosystem services provided by these agroforestry systems in the 
form of subsidies or other payments to landowners in return for the long-term economic sustainability of this low-intensity productive system $[8,117,118]$.

Author Contributions: M.P.R.-R., S.R. and D.S.-M. conceived the paper. All authors have contributed to the literature review and to the writing. All authors have read and agreed to the published version of the manuscript.

Funding: This research received no external funding.

Institutional Review Board Statement: Not applicable.

Informed Consent Statement: Not applicable.

Data Availability Statement: Not applicable.

Conflicts of Interest: The authors declare no conflict of interest.

\section{References}

1. Keenleyside, C.; Beaufoy, G.; Tucker, G.; Jones, G. High Nature Value farming throughout EU-27 and its financial support under the CAP. In Report Prepared for DG Environment; Contract No ENV B.1/ETU/2012/0035; Institute for European Environmental Policy: London, UK, 2014.

2. Moreno, G.; Aviron, S.; Berg, S.; Crous-Duran, J.; Franca, A.; de Jalón, S.G.; Hartel, T.; Mirck, J.; Pantera, A.; Palma, J.H.N.; et al. Agroforestry Systems of High Nature and Cultural Value in Europe: Provision of Commercial Goods and Other Ecosystem Services. Agrofor. Syst. 2018, 92, 877-891. [CrossRef]

3. Moreno, G.; Franca, A.; Pinto-Correia, T.; Godinho, S. Multifunctionality and Dynamics of Silvopastoral Systems View Project. Options Méditerranéennes 2014, 109, 421-436.

4. European Commission. Interpretation Manual of European Union Habitats-EUR28; European Commission, DG Environment: Brussels, Belgium, 2013.

5. Manning, A.D.; Fischer, J.; Lindenmayer, D.B. Scattered Trees are Keystone Structures-Implications for Conservation. Biol. Conserv. 2006, 132, 311-321. [CrossRef]

6. Vogiatzakis, I.N.; Mannion, A.M.; Griffiths, G.H. Mediterranean Ecosystems: Problems and Tools for Conservation. Prog. Phys. Geogr. 2006, 30, 175-200. [CrossRef]

7. Díaz, M.; Pulido, J.F. 6310 Dehesas Perennifolias de Quercus spp. In Bases Ecológicas Preliminares Para la Conservación de los Tipos de Hábitat de Interés Comunitario en España; Ministerio de Medio Ambiente, Medio Rural y Marino: Madrid, Spain, 2009; pp. 1-69.

8. Plieninger, T.; Van Der Horst, D.; Schleyer, C.; Bieling, C. Sustaining Ecosystem Services in Cultural Landscapes: Analysis and Management Options Sustaining Ecosystem Services in Cultural Landscapes. Ecol. Soc. 2014, 19, art59. [CrossRef]

9. Bugalho, M.N.; Dias, F.S.; Briñas, B.; Cerdeira, J.O. Using the High Conservation Value Forest Concept and Pareto Optimization to Identify Areas Maximizing Biodiversity and Ecosystem Services in Cork Oak Landscapes. Agrofor. Syst. 2016, 90, 35-44. [CrossRef]

10. Oggioni, S.D.; Ochoa-Hueso, R.; Peco, B. Livestock Grazing Abandonment Reduces Soil Microbial Activity and Carbon Storage in a Mediterranean Dehesa. Appl. Soil Ecol. 2020, 153, 103588. [CrossRef]

11. Andersen, E.; Baldock, D.; Bennett, H.; Beaufoy, G.; Bignal, E.; Brouwer, F.; Elbersen, B.; Eiden, G.; Godeschalk, F.; Jones, G.; et al. Developing a High Nature Value Farming Area Indicator; Internal Report for the European Environment Agency; Institute for European Environmental Policy: Brussels, Belgium, 2003.

12. Eichhorn, M.P.; Paris, P.; Herzog, F.; Incoll, L.D.; Liagre, F.; Mantzanas, K.; Mayus, M.; Moreno, G.; Papanastasis, V.P.; Pilbeam, D.J.; et al. Silvoarable Systems in Europe-Past, Present and Future Prospects. Agrofor. Syst. 2006, 67, 29-50. [CrossRef]

13. Acebes, P.; Pereira, D.; Oñate, J.J. Towards the Identification and Assessment of HNV Dehesas: A Meso-Scale Approach. Agrofor. Syst. 2016, 90, 7-22. [CrossRef]

14. Hernández-Lambraño, R.E.; de la Cruz, D.R.; Sánchez-Agudo, J.Á. Spatial Oak Decline Models to Inform Conservation Planning in the Central-Western Iberian Peninsula. For. Ecol. Manag. 2019, 441, 115-126. [CrossRef]

15. Plieninger, T.; Rolo, V.; Moreno, G. Large-Scale Patterns of Quercus ilex, Quercus suber, and Quercus pyrenaica Regeneration in Central-Western Spain. Ecosystems 2010, 13, 644-660. [CrossRef]

16. Simões, M.P.; Belo, A.F.; Fernandes, M.; Madeira, M. Regeneration Patterns of Quercus Suber According to Montado Management Systems. Agrofor. Syst. 2016, 90, 107-115. [CrossRef]

17. Almeida, M.; Azeda, C.; Guiomar, N.; Pinto-Correia, T. The Effects of Grazing Management in Montado Fragmentation and Heterogeneity. Agrofor. Syst. 2016, 90, 69-85. [CrossRef]

18. Godinho, S.; Guiomar, N.; Machado, R.; Santos, P.; Sá-Sousa, P.; Fernandes, J.P.; Neves, N.; Pinto-Correia, T. Assessment of Environment, Land Management, and Spatial Variables on Recent Changes in Montado Land Cover in Southern Portugal. Agrofor. Syst. 2016, 90, 177-192. [CrossRef]

19. Acosta Naranjo, R. Dehesas de la Sobremodernidad. La Cadencia y el Vértigo; Diputación Provincial de Badajoz: Badajoz, Spain, 2008.

20. Junta de Andalucía. Plan Director de las Dehesas de Andalucía; Technical Report; Junta de Andalucía: Sevilla, Spain, 2017. 
21. Díaz, M.; Campos, P.; Pulido, F.J. The Spanish dehesas: A diversity in land-use and wildlife. In Farming and Birds in Europe: The Common Agricultural Policy and Its Implications for Bird Conservation; Pain, D., Pienkowski, M., Eds.; Academic Press: London, UK, 1997; pp. 178-209.

22. Moreno, G.; Cáceres, Y. System Report: Iberian Dehesas, Spain. AGFORWARD Project Report, 2016. Available online: www. agforward.eu (accessed on 19 December 2021).

23. Pineda, F.D.; Nicolas, J.P.; Ruiz, M.; Bernaldez, F.G. Succession, Diversité et Amplitude de Niche Dans Les Pâturages Du Centre de La Péninsule Ibérique. Vegetatio 1981, 46, 267-277. [CrossRef]

24. Marañón, T. Diversidad Florística y Heterogeneidad Ambiental En Una Dehesa de Sierra Morena. An. Edafol. Abrobiologia 1985, 44, 1183-1197.

25. Rico, M.; Puerto, A. Estructura Básica Generada Por El Arbolado En Pastos Semiáridos (Ecosistemas de Dehesa). Pastos 1988, 1819, 13-28.

26. Puerto, A.; Rico, M.; Matías, M.D.; García, J.A. Variation in Structure and Diversity in Mediterranean Grasslands Related to Trophic Status and Grazing Intensity. J. Veg. Sci. 1990, 1, 445-452. [CrossRef]

27. Díaz, M. Biodiversity in the Dehesa. In Agroforestry Systems as a Technique for Sutainable Land Management; Mosquera-Losada, M.R., Fernández-Lorenzo, J.L., Rigueiro-Rodríguez, A., Eds.; Programme Azahar, AECID: Madrid, Spain, 2009; pp. $209-225$.

28. Bugalho, M.N.; Lecomte, X.; Gonçalves, M.; Caldeira, M.C.; Branco, M. Establishing Grazing and Grazing-Excluded Patches Increases Plant and Invertebrate Diversity in a Mediterranean Oak Woodland. For. Ecol. Manag. 2011, 261, 2133-2139. [CrossRef]

29. Moreno, G.; Gonzalez-Bornay, G.; Pulido, F.; Lopez-Diaz, M.L.; Bertomeu, M.; Juárez, E.; Diaz, M. Exploring the Causes of High Biodiversity of Iberian Dehesas: The Importance of Wood Pastures and Marginal Habitats. Agrofor. Syst. 2016, 90, 87-105. [CrossRef]

30. Simonson, W.D.; Allen, H.D.; Parham, E.; de Basto e Santos, E.; Hotham, P. Modelling Biodiversity Trends in the Montado (Wood Pasture) Landscapes of the Alentejo, Portugal. Landsc. Ecol. 2018, 33, 811-827. [CrossRef]

31. Díaz, M.; González, E.; Muñoz-Pulido, R.; Naveso, M.A. Habitat Selection Patterns of Common Cranes Grus grus Wintering in Holm oak Quercus Ilex Dehesas of Central Spain: Effects of Human Management. Biol. Conserv. 1996, 75, 119-123. [CrossRef]

32. Avilés, J.M. Common Cranes Grus grus and Habitat Management in Holm Oak Dehesas of Spain. Biodivers. Conserv. 2004, 13, 2015-2025. [CrossRef]

33. Carrete, M.; Donázar, J.A. Application of Central-Place Foraging Theory Shows the Importance of Mediterranean Dehesas for the Conservation of the Cinereous Vulture, Aegypius Monachus. Biol. Conserv. 2005, 126, 582-590. [CrossRef]

34. Martin-Díaz, P.; Cortés-Avizanda, A.; Serrano, D.; Arrondo, E.; Sánchez-Zapata, J.A.; Donázar, J.A. Rewilding Processes Shape the Use of Mediterranean Landscapes by an Avian Top Scavenger. Sci. Rep. 2020, 10, 2853. [CrossRef] [PubMed]

35. Marañón, T. Plant Species Richness and Canopy Effect in the Savanna-like "dehesa" of SW Spain. Ecol. Mediterr. 1986, 12, 131-141. [CrossRef]

36. Díez, C.; Luis, E.; Tárrega, R. Variación de la diversidad y organización de la comunidad herbácea en robledales adehesados de Quercus pyrenaica. In Proceedings of the 32th Reunión Científica de la SEEP, Pamplona, Spain, 1-5 June 1992; pp. $128-133$.

37. Fernández-Moya, J.; Miguel-Ayanz, A.S.; Cañellas, I.; Gea-Izquierdo, G. Variability in Mediterranean Annual Grassland Diversity Driven by Small-Scale Changes in Fertility and Radiation. Plant Ecol. 2011, 212, 865-877. [CrossRef]

38. López-Carrasco, C.; López-Sánchez, A.; San Miguel, A.; Roig, S. The Effect of Tree Cover on the Biomass and Diversity of the Herbaceous Layer in a Mediterranean Dehesa. Grass Forage Sci. 2015, 70, 639-650. [CrossRef]

39. López-Sánchez, A.; San Miguel, A.; Dirzo, R.; Roig, S. Scattered Trees and Livestock Grazing as Keystones Organisms for Sustainable Use and Conservation of Mediterranean Dehesas. J. Nat. Conserv. 2016, 33, 58-67. [CrossRef]

40. López-Sánchez, A.; San Miguel, A.; López-Carrasco, C.; Huntsinger, L.; Roig, S. The Important Role of Scattered Trees on the Herbaceous Diversity of a Grazed Mediterranean Dehesa. Acta Oecologica 2016, 76, 31-38. [CrossRef]

41. Rolo, V.; Rivest, D.; López-Díaz, M.L.; Moreno, G. Microhabitat effects on herbaceous nutrient concentrations at the communit [y and species level in Mediterranean open woodlands: The role of species composition. Grass Forage Sci. 2015, 70, 219-228. [CrossRef]

42. Rolo, V.; Rivest, D.; Lorente, M.; Kattge, J.; Moreno, G. Taxonomic and functional diversity in Mediterranean pastures: Insights on the biodiversity-productivity trade-off. J. Appl. Ecol. 2016, 53, 1575-1584. [CrossRef]

43. Reyes-López, J.; Ruiz, N.; Fernández-Haeger, J. Community Structure of Ground-Ants: The Role of Single Trees in a Mediterranean Pastureland. Acta Oecologica 2003, 24, 195-202. [CrossRef]

44. Gaytán, Á.; Bautista, J.L.; Bonal, R.; Moreno, G.; González-Bornay, G. Trees Increase Ant Species Richness and Change Community Composition in Iberian Oak Savannahs. Diversity 2021, 13, 115. [CrossRef]

45. Martins da Silva, P.; Aguiar, C.A.S.; Niemelä, J.; Sousa, J.P.; Serrano, A.R.M. Cork-Oak Woodlands as Key-Habitats for Biodiversity Conservation in Mediterranean Landscapes: A Case Study Using Rove and Ground Beetles (Coleoptera: Staphylinidae, Carabidae). Biodivers. Conserv. 2009, 18, 605-619. [CrossRef]

46. Ramírez-Hernández, A.; Micó, E.; de los Ángeles Marcos-García, M.; Brustel, H.; Galante, E. The "dehesa", a Key Ecosystem in Maintaining the Diversity of Mediterranean Saproxyliclinsects (Coleoptera and Diptera: Syrphidae). Biodivers. Conserv. 2014, 23, 2069-2086. [CrossRef]

47. García-Tejero, S.; Taboada, A. Microhabitat Heterogeneity Promotes Soil Fertility and Ground-Dwelling Arthropod Diversity in Mediterranean Wood-Pastures. Agric. Ecosyst. Environ. 2016, 233, 192-201. [CrossRef] 
48. Cárdenas, A.M.; Gallardo, P.; Salido, Á.; Márquez, J. Effects of Environmental Traits and Landscape Management on the Biodiversity of Saproxylic Beetles in Mediterranean Oak Forests. Diversity 2020, 12, 451. [CrossRef]

49. Ricarte, A.; Nencioni, A.; Tubić, N.K.; Grković, A.; Vujić, A.; Marcos-García, M.Á. The Hoverflies of an Oak Dehesa from Spain, with a New Species and Other Insights into the Taxonomy of the Eumerus Tricolor Group (Diptera: Syrphidae). Ann. Zool. 2018, 68, 259-280. [CrossRef]

50. Santos-Silva, C.; Gonçalves, A.; Louro, R. Canopy Cover Influence on Macrofungal Richness and Sporocarp Production in Montado Ecosystems. Agrofor. Syst. 2011, 82, 149-159. [CrossRef]

51. Canteiro, C.; Pinto-Cruz, C.; Simões, M.P.; Gazarini, L. Conservation of Mediterranean Oak Woodlands: Understorey Dynamics under Different Shrub Management. Agrofor. Syst. 2011, 82, 161-171. [CrossRef]

52. Martín, J.; Lopez, P. The Effect of Mediterranean Dehesa Management on Lizard Distribution and Conservation. Biol. Conserv. 2002, 108, 213-219. [CrossRef]

53. Godinho, S.; Santos, A.P.; Sá-Sousa, P. Montado Management Effects on the Abundance and Conservation of Reptiles in Alentejo, Southern Portugal. Agrofor. Syst. 2011, 82, 197-207. [CrossRef]

54. Oksuz, D.P.; Aguiar, C.A.S.; Tápia, S.; Llop, E.; Lopes, P.; Serrano, A.R.M.; Leal, A.I.; Branquinho, C.; Correia, O.; Rainho, A.; et al. Increasing Biodiversity in Wood-Pastures by Protecting Small Shrubby Patches. For. Ecol. Manag. 2020, 464, 118041. [CrossRef]

55. Slancarova, J.; Garcia-Pereira, P.; Fric, Z.F.; Romo, H.; Garcia-Barros, E. Butterflies in Portuguese 'Montados': Relationships between Climate, Land Use and Life-History Traits. J. Insect Conserv. 2015, 19, 823-836. [CrossRef]

56. Azul, A.M.; Sousa, J.P.; Agerer, R.; Martín, M.P.; Freitas, H. Land Use Practices and Ectomycorrhizal Fungal Communities from Oak Woodlands Dominated by Quercus suber L. Considering Drought Scenarios. Mycorrhiza 2010, 20, 73-88. [CrossRef]

57. Azul, A.M.; Mendes, S.M.; Sousa, J.P.; Freitas, H. Fungal Fruitbodies and Soil Macrofauna as Indicators of Land Use Practices on Soil Biodiversity in Montado. Agrofor. Syst. 2011, 82, 121-138. [CrossRef]

58. Barrico, L.; Rodríguez-Echeverría, S.; Freitas, H. Diversity of Soil Basidiomycete Communities Associated with Quercus suber L. in Portuguese Montados. Eur. J. Soil Biol. 2010, 46, 280-287. [CrossRef]

59. Santos-Silva, C.; Louro, R. Assessment of the Diversity of Epigeous Basidiomycota under Different Soil-Management Systems in a Montado Ecosystem: A Case Study Conducted in Alentejo. Agrofor. Syst. 2016, 90, 117-126. [CrossRef]

60. Mendes, S.M.; Santos, J.; Freitas, H.; Sousa, J.P. Assessing the Impact of Understory Vegetation Cut on Soil Epigeic Macrofauna from a Cork-Oak Montado in South Portugal. Agrofor. Syst. 2011, 82, 139-148. [CrossRef]

61. Peco, B.; Espigares, T.; Levassor, C. Trends and fluctuations in species abundance and richness in Mediterranean annual pastures. Appl. Veg. Sci. 1998, 1, 21-28. [CrossRef]

62. Peco, B.; Sánchez, A.M.; Azcárate, F.M. Abandonment in Grazing Systems: Consequences for Vegetation and Soil. Agric. Ecosyst. Environ. 2006, 113, 284-294. [CrossRef]

63. Carmona, C.P.; Azcárate, F.M.; de Bello, F.; Ollero, H.S.; Lepš, J.; Peco, B. Taxonomical and Functional Diversity Turnover in Mediterranean Grasslands: Interactions between Grazing, Habitat Type and Rainfall. J. Appl. Ecol. 2012, 49, 1084-1093. [CrossRef]

64. del Barrio, J.M.G.; Ponce, R.A.; Benavides, R.; Roig, S. Species Richness and Similarity of Vascular Plants in the Spanish Dehesas at Two Spatial Scales. For. Syst. 2014, 23, 111-119. [CrossRef]

65. Rico Rodríguez, M.; García Criado, L.; García Criado, B.; García Ciudad, A. Efecto de Fertilizantes Fosfatados Sobre La Composición Florística de Pastizales Seminaturales En Suelos Ácidos. Pastos 1985, 15, 139-158.

66. López-Carrasco, C.; Gómez, M.; Carpintero, J.; Brañas, J.; Roig, S. Efectos de la aplicación de fertilizantes de nueva generación en la dehesa toledana: Producción y diversidad de pastos herbáceos. In Nuevos Retos de la Ganadería Extensiva: Un Agente de Conservación en Peligro de Extinción; Canals, R.M., San Emeterio, L., Eds.; Sociedad Española para el Estudio de Pastos: Pamplona, Spain, 2012; pp. 29-35.

67. López-Carrasco, C.; López-Sánchez, A.; Gómez, M.; Carpintero, J.; Brañas, J.; Roig, S. Efectos de la aplicación de fertilizantes de nueva generación en la dehesa toledana: Producción, diversidad y composición florística de pastos herbáceos. In Los Pastos: Nuevos Retos, Nuevas Oportunidades; Olea, L., Poblaciones, M.J., Rodrigo, S.M., Santamaría, O., Eds.; Sociedad Española para el Estudio de Pastos: Pamplona, Spain, 2013; pp. 545-552.

68. López-Carrasco, C.; Gómez, M.J.; Carpintero, J.M.; Brañas, J.; Roig, S. Efecto residual de la aplicación de fertilizantes de nueva generación sobre la producción, composición y diversidad de pastos herbáceos en una dehesa toledana. In Proceedings of the 53th Reunión Científica de la SEEP, Potes, Spain, 9-12 June 2014; pp. 215-222.

69. Tárrega, R.; Calvo, L.; Taboada, Á.; García-Tejero, S.; Marcos, E. Abandonment and Management in Spanish Dehesa Systems: Effects on Soil Features and Plant Species Richness and Composition. For. Ecol. Manag. 2009, 257, 731-738. [CrossRef]

70. Castro, H.; Lehsten, V.; Lavorel, S.; Freitas, H. Functional Response Traits in Relation to Land Use Change in the Montado. Agric. Ecosyst. Environ. 2010, 137, 183-191. [CrossRef]

71. Rueda, M.; Rebollo, S.; García-Salgado, G. Contrasting Impacts of Different-Sized Herbivores on Species Richness of Mediterranean Annual Pastures Differing in Primary Productivity. Oecologia 2013, 172, 449-459. [CrossRef]

72. Köbel, M.; Listopad, C.M.C.S.; Príncipe, A.; Nunes, A.; Branquinho, C. Temporary Grazing Exclusion as a Passive Restoration Strategy in a Dryland Woodland: Effects over Time on Tree Regeneration and on the Shrub Community. For. Ecol. Manag. 2021, 483, 118732. [CrossRef]

73. Aragón, G.; López, R.; Martínez, I. Effects of Mediterranean Dehesa Management on Epiphytic Lichens. Sci. Total Environ. 2010, 409, 116-122. [CrossRef] 
74. Azcárate, F.M.; Peco, B. Abandonment of Grazing in a Mediterranean Grassland Area: Consequences for Ant Assemblages. Insect Conserv. Divers. 2012, 5, 279-288. [CrossRef]

75. García-Tejero, S.; Taboada, Á.; Tárrega, R.; Salgado, J.M. Land Use Changes and Ground Dwelling Beetle Conservation in Extensive Grazing Dehesa Systems of North-West Spain. Biol. Conserv. 2013, 161, 58-66. [CrossRef]

76. Barriga, J.C.; Lassaletta, L.; Moreno, A.G. Ground-Living Spider Assemblages from Mediterranean Habitats under Different Management Conditions. J. Arachnol. 2010, 38, 258-269. [CrossRef]

77. Arosa, M.L.; Freitas, H.; Costa, S.R. Temporal Effects Dominate Land Use as Factors Affecting Soil Nematode Communities in Mediterranean Oak Woodlands. Agrofor. Syst. 2016, 90, 127-136. [CrossRef]

78. Pulido, F.J.; Díaz, M. Relaciones entre la estructura de la vegetación y las comunidades de aves nidificantes en las dehesas: Influencia del manejo humano. Ardeola 1992, 39, 63-72.

79. Godinho, C.; Rabaça, J.E. Birds like It Corky: The Influence of Habitat Features and Management of "montados" in Breeding Bird Communities. Agrofor. Syst. 2011, 82, 183-195. [CrossRef]

80. Catarino, L.; Godinho, C.; Pereira, P.; Luís, A.; Rabaça, J.E. Can Birds Play a Role as High Nature Value Indicators of Montado System? Agrofor. Syst. 2016, 90, 45-56. [CrossRef]

81. Oksuz, D.P.; Palmeirim, J.M.; Correia, R.A. Bird Taxonomic and Functional Responses to Land Abandonment in Wood-Pastures. Agrofor. Syst. 2021, 95, 1167-1176. [CrossRef]

82. Díaz, M.; González, E.; Muñoz-Pulido, R.; Naveso, M.A. Abundance, seed predation rates, and body condition of rodents wintering in Spanish Holm-oak Quercus ilex L. dehesas and cereal croplands: Effects of food abundance and habitat structure. Mamm. Biol. 1993, 58, 302-311.

83. Jiménez-Carmona, F.; Carpintero, S.; Reyes-López, J.L. Ants (Hymenoptera: Formicidae) as Surrogates for Epigeic Arthropods in Northern Andalusian "dehesas" (Spain). Sociobiology 2020, 67, 201-212. [CrossRef]

84. Martins da Silva, P.; Aguiar, C.A.S.; de e Silva, I.F.; Serrano, A.R.M. Orchard and Riparian Habitats Enhance Ground Dwelling Beetle Diversity in Mediterranean Agro-Forestry Systems. Biodivers. Conserv. 2011, 20, 861-872. [CrossRef]

85. Tellería, J.L. Passerine Bird Communities of Iberian Dehesas: A Review. Anim. Biodivers. Conserv. 2001, $24,67-78$.

86. Díaz, M.; Pulido, F.J.; Marañón, T. Diversidad Biológica y Sostenibilidad Ecológica y Económica de Los Sistemas Adehesados. Ecosistemas 2003, 12, 1-10. [CrossRef]

87. Rosalino, L.M.; do Rosário, J.; Santos-Reis, M. The Role of Habitat Patches on Mammalian Diversity in Cork Oak Agroforestry Systems. Acta Oecol. 2009, 35, 507-512. [CrossRef]

88. Gonçalves, P.; Alcobia, S.; Simões, L.; Santos-Reis, M. Effects of Management Options on Mammal Richness in a Mediterranean Agro-Silvo-Pastoral System. Agrofor. Syst. 2012, 85, 383-395. [CrossRef]

89. Curveira-Santos, G.; Marques, T.A.; Björklund, M.; Santos-Reis, M. Mediterranean Mesocarnivores in Spatially Structured Managed Landscapes: Community Organisation in Time and Space. Agric. Ecosyst. Environ. 2017, 237, 280-289. [CrossRef]

90. Costa, P.; Medinas, D.; Silva, B.M.; Mira, A.; Guiomar, N.; Sales-Baptista, E.; Ferraz-de-Oliveira, M.I.; Simões, M.P.; Belo, A.D.F.; Herrera, J.M. Cattle-Driven Forest Disturbances Impact Ensemble Composition and Activity Levels of Insectivorous Bats in Mediterranean Wood Pastures. Agrofor. Syst. 2019, 93, 1687-1699. [CrossRef]

91. Hernández-Esteban, A.; Rolo, V.; López-Díaz, M.L.; Moreno, G. Long-Term Implications of Sowing Legume-Rich Mixtures for Plant Diversity of Mediterranean Wood Pastures. Agric. Ecosyst. Environ. 2019, 286, 106686. [CrossRef]

92. Leal, A.I.; Correia, R.A.; Granadeiro, J.P.; Palmeirim, J.M. Impact of Cork Extraction on Birds: Relevance for Conservation of Mediterranean Biodiversity. Biol. Conserv. 2011, 144, 1655-1662. [CrossRef]

93. Leal, A.I.; Correia, R.A.; Palmeirim, J.M.; Granadeiro, J.P. Does Canopy Pruning Affect Foliage-Gleaning Birds in Managed Cork Oak Woodlands? Agrofor. Syst. 2013, 87, 355-363. [CrossRef]

94. López-Sánchez, A.; Perea, R.; Roig, S. Are Large-Nested Bird Colonies Compatible with the Conservation of Grazed Woodlands? Glob. Ecol. Conserv. 2019, 20, e00705. [CrossRef]

95. Margalef, R. Ecología; Omega: Barcelona, Spain, 1974.

96. Grime, J.P. Plant Strategies and Vegetation Processes; Wiley: Chichester, UK, 1979.

97. San Miguel, A.; Roig, S.; Perea, R. The pastures of Spain. Pastos 2016, 46, 6-39.

98. Olea, L.; San Miguel, A. The Spanish dehesa. A traditional Mediterranean silvopastoral system linking production and nature conservation. Grassl. Sci. Eur. 2006, 11, 3-13.

99. Murillo, M.; González, F. Gestión de la dehesa en Extremadura. Recursos pascícolas y mejoras. Pastos 2008, 38, 5-7.

100. Hernando Varela, J. El proyecto de investigación agrícola del Banco Mundial y la modernización de la investigación agraria en España en la década de los setenta. Estud. Agrosoc. Pesq. 2001, 190, 43-63.

101. Katznelson, J. Aspectos económicos de la aplicación de fertilizantes en pastos de secano naturales y artificiales. Pastos 1975, 5 , 84-98.

102. Olea, L.; Paredes, J.; González, J.D.; Santos, A. Influencia de la sequía en la persistencia de leguminosas anuales y en la fertilidad de los suelos de pastos del SO de España. In Proceedings of the 24th Reunión Científica de la SEEP, Santander, Spain, 30 May-3 June 1994; pp. 103-109.

103. Perea, R.; López-Sánchez, A.; Roig, S. The Use of Shrub Cover to Preserve Mediterranean Oak Dehesas: A Comparison between Sheep, Cattle and Wild Ungulate Management. Appl. Veg. Sci. 2016, 19, 244-253. [CrossRef] 
104. Moreno, G.; Bartolome, J.W.; Gea-Izquierdo, G.; Cañellas, I. Overstory-understorey relationships. In Mediterranean oak Woodland Working Landscapes; Campos, P., Huntsinger, L., Oviedo, J.L., Starrs, P.F., Diaz, M., Standiford, R.B., Montero, G., Eds.; Springer: Dordrecht, The Netherlands, 2013; pp. 145-179.

105. Rossetti, I.; Bagella, S.; Cappai, C.; Caria, M.C.; Lai, R.; Roggero, P.P.; da Silva, P.M.; Sousa, J.P.; Querner, P.; Seddaiu, G. Isolated Cork Oak Trees Affect Soil Properties and Biodiversity in a Mediterranean Wooded Grassland. Agric. Ecosyst. Environ. 2015, 202, 203-216. [CrossRef]

106. García Moreno, A.M.; Fernández Rebollo, P.; Muñoz Espejo, M.L.; Carbonero Muñoz, M.D. Gestión de los Pastos en la Dehesa; Instituto de Investigación y Formación Agraria y Pequera: Sevilla, Spain, 2016; pp. 1-138.

107. Pereira, M.; Rodríguez, A. Conservation Value of Linear Woody Remnants for Two Forest Carnivores in a Mediterranean Agricultural Landscape. J. Appl. Ecol. 2010, 47, 611-620. [CrossRef]

108. Ribeiro, S.; Fernandes, J.P.; Espírito-Santo, M.D. Diversity and Floristic Patterns of Mediterranean Grasslands: The Relative Influence of Environmental and Land Management Factors. Biodivers. Conserv. 2014, 23, 2903-2921. [CrossRef]

109. Faria, N. Predicting Agronomical and Ecological Effects of Shifting from Sheep to Cattle Grazing in Highly Dynamic Mediterranean Dry Grasslands. Land Degrad. Dev. 2019, 30, 300-314. [CrossRef]

110. Faria, N.; Morales, M.B. Farmland Management Regulates Ecosystem Services in Mediterranean Drylands: Assessing the Sustainability of Agri-Environmental Payments for Bird Conservation. J. Nat. Conserv. 2020, 58, 125913. [CrossRef]

111. Ramos, R.F.; Diogo, J.A.; Santana, J.; Silva, J.P.; Reino, L.; Schindler, S.; Beja, P.; Lomba, A.; Moreira, F. Impacts of Sheep versus Cattle Livestock Systems on Birds of Mediterranean Grasslands. Sci. Rep. 2021, 11, 10827. [CrossRef] [PubMed]

112. Peco, B.; Navarro, E.; Carmona, C.P.; Medina, N.G.; Marques, M.J. Effects of Grazing Abandonment on Soil Multifunctionality: The Role of Plant Functional Traits. Agric. Ecosyst. Environ. 2017, 249, 215-225. [CrossRef]

113. Moreno, G.; Hernández-Esteban, A.; Rolo, V.; Igual, J.M. The enduring effects of sowing legume-rich mixtures on the soil microbial community and soil carbon in semi-arid wood pastures. Plant Soil 2021, 465, 563-582. [CrossRef]

114. Hevia, V.; Carmona, C.P.; Azcárate, F.M.; Torralba, M.; Alcorlo, P.; Ariño, R.; Lozano, J.; Castro-Cobo, S.; González, J.A. Effects of Land Use on Taxonomic and Functional Diversity: A Cross-Taxon Analysis in a Mediterranean Landscape. Oecologia 2016, 181, 959-970. [CrossRef] [PubMed]

115. Rocha, B.; Pinho, P.; Branquinho, C.; Boieiro, M.; Matos, P. Bringing the Concept of Ammonia Critical Levels into Managing Cork-Oak Woodland for Conservation. For. Ecol. Manag. 2019, 453, 117566. [CrossRef]

116. Oksuz, D.P.; Aguiar, C.A.S.; Tápia, S.; Llop, E.; Lopes, P.; Serrano, A.R.M.; Leal, A.I.; Correia, O.; Matos, P.; Rainho, A.; et al. The Contribution of Small Shrubby Patches to the Functional Diversity of Wood-Pastures. Acta Oecol. 2020, 108, 103626. [CrossRef]

117. Díaz, M.; Tietje, W.D.; Barret, R.H. Effects of Management on Biological Diversity and Endangered Species. In Mediterranean oak Woodland Working Landscapes; Campos, P., Huntsinger, L., Oviedo, J.L., Starrs, P.F., Diaz, M., Standiford, R.B., Montero, G., Eds.; Springer: Dordrecht, The Netherlands, 2013; pp. 213-243.

118. Mupepele, A.-C.; Bruelheide, H.; Brühl, C.; Dauber, J.; Fenske, M.; Freibauer, A.; Gerowitt, B.; Kruß, A.; Lankner, S.; Plieninger, T.; et al. Biodiversity in agricultural landscapes: Transformative societal changes needed. Trends Ecol. Evol. 2021, 36, 1067-1070. [CrossRef] 